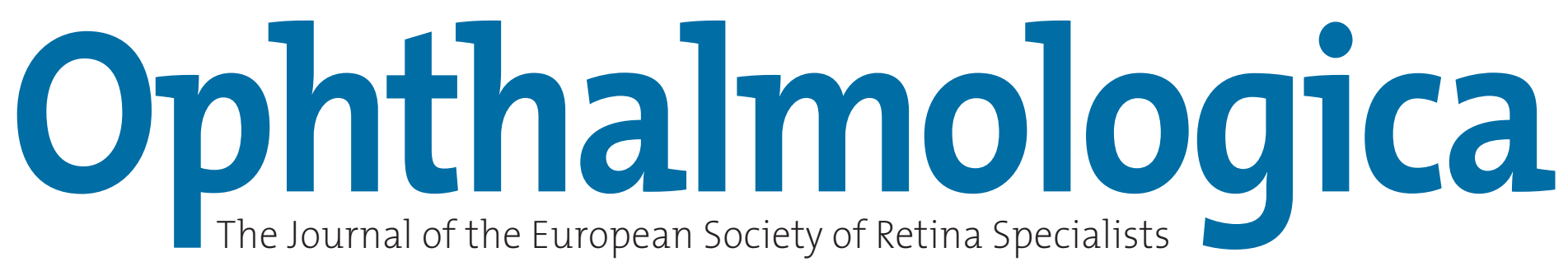

\title{
EURETINA
}

European Society of Retina Specialists

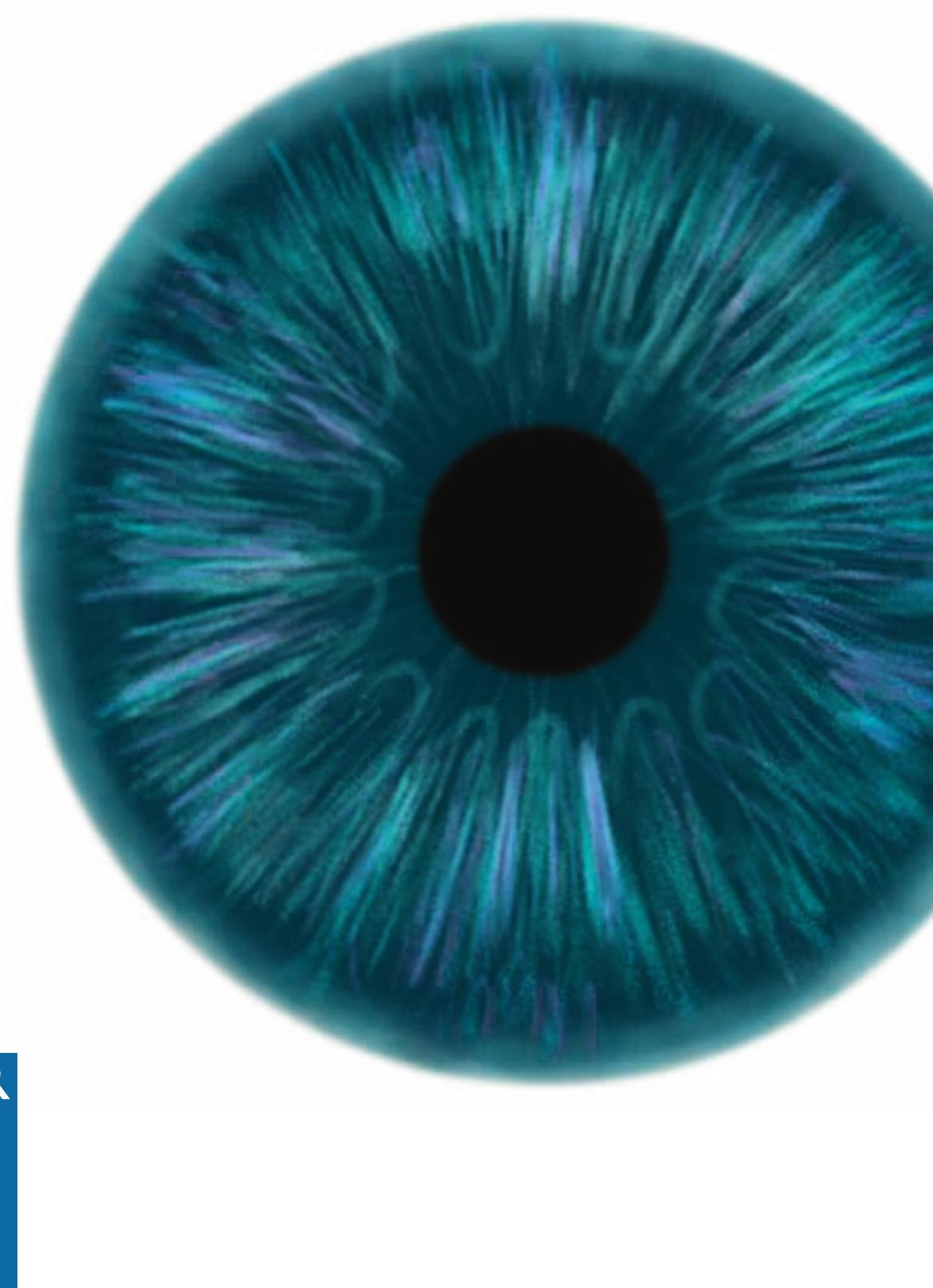




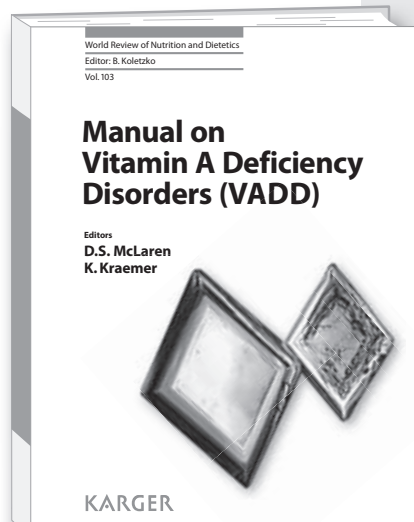

\title{
Manual on Vitamin A Deficiency Disorders (VADD)
}

\author{
Editors \\ Donald S. McLaren \\ Klaus Kraemer
}

Manual on Vitamin A Deficiency Disorders (VADD)

Editors: McLaren, D.S. (Worthing)

Kraemer, K. (Basel)

XII + 192 p., 76 fig., 4 in color, 55 tab., 2012

CHF 196.- / EUR 163.- / USD 231.00 (hard cover) CHF 235.- / EUR 196.- / USD 277.00 (online)

Online version for institutional purchase

Prices subject to change

EUR price for Germany, USD price for USA only ISBN 978-3-318-02143-1 (hard cover)

e-ISBN 978-3-318-02144-8

World Review of Nutrition and Dietetics, Vol. 103

Series Editor: Koletzko, B. (Munich)

Listed in MEDLINE/PubMed

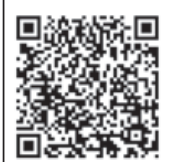

Dear Librarian

I have reviewed this publication and would like to recommend it for our library.

\section{Recommended by:}

Department:

Date:

Orders may be placed with any bookshop,
Vitamin A plays a key role among the vitamins essential for healthy growth and development. Vitamin A deficiency disorders (VADD) are therefore an important part of general malnutrition that in the majority of cases leads to failure to thrive and underweight. Moreover, apart from adverse effects on health and survival in general, VADD can also lead to blindness, called xerophthalmia, and are also frequently accompanied by various infections. Last but not least, it has become evident that even mild degrees of VAD (and all other forms of nutritional deficiencies) have important adverse implications for health and are thus much more widespread than previously assumed.

This publication systematically covers detailed and up-to-date information on every relevant aspect of VADD, with particular emphasis on providing an outline of their setting, nature, and significance. In addition to cutting-edge scientific information, the latest available data on the global occurrence of VAD from the World Health Organization is also included.

\section{Contents}

Acknowledgements

Preface

Foreword

- Foreground

- Vitamin A in Nature

- Methods of Analysis

- Food Sources

- Bioavailability of Carotenoids

- Vitamin A in Health

- Assessment of Vitamin A Status

- Xerophthalmia

- Mortality and Morbidity Especially in Relation to Infections

- Other Effects of VAD

- Interaction of Vitamin A and Other Micronutrients

- Global Occurrence

- Epidemiology

- Retinoids and Carotenoids in General Medicine

- Control 


\section{Ophthalmologica}

\section{International Journal of Ophthalmology}

Founded 1899 as 'Zeitschrift für Augenheilkunde' by H. Kuhnt and J. von Michel Continued by J. Meller (1923-1938), C. Behr (1925-1938), A. Brückner (1938-1959), H.J.M. Weve (1938-1962), H.M. Dekking (1954-1966), J. ten Doesschate (1967-1971), J. François (1959-1979), E.B. Streiff (1954-1979), H. Sautter (1979-1984), W. Straub (1979-1993), Ch. Ohrloff (1994-2009)

\section{Editor}

\section{J. Cunha-Vaz, Coimbra}

\section{Associate Editors}

G.W. Aylward, London

J. Bainbridge, London

F. Bandello, Milan

R. Belfort Jr., São Paulo

G. Coscas, Créteil

J.C.N. Murta, Coimbra

R.J. Olson, Salt Lake City, Utah

N. Pfeiffer, Mainz

G. Richard, Hamburg

S. Wolf, Bern

\section{Editorial Board}

J.L. Alió, Alicante

D. Balasubramanian, Hyderabad

R. Bernardes, Coimbra

A.J. Bron, Oxford

V. Chong, Oxford

B. Corcóstegui, Barcelona

A. Cruess, Halifax, N.S.

R. Dana, Boston, Mass.

A. Gaudric, Paris

F. Holz, Bonn

Y.N. Hui, Xian

J.B. Jonas, Mannheim

P. Kestelyn, Gent

P.T. Khaw, London

I.K. Kim, Boston, Mass.

T. Kohnen, Frankfurt

C. Lobo, Coimbra

A. Loewenstein, Tel Aviv

B. Lorenz, Giessen

P. Massin, Paris

E. Midena, Padova
A. Negi, Kobe

Y. Ogura, Nagoya

J.C. Pastor Jimeno, Valladolid

U. Pleyer, Berlin

L. Rossetti, Milan

J.A. Sahel, Paris

U. Schmidt-Erfurth, Vienna

R. Silva, Coimbra

E. Stefánsson, Reykjavík

M.J. Tassignon, Antwerp

K. Tsubota, Tokyo

A. Tufail, London

M. Ulbig, Munich

P. Wiedemann, Leipzig

D. Wong, Liverpool

T.Y. Wong, Singapore

$\mathrm{X}$. Xu, Shanghai

T. Zeyen, Louvain

L. Zografos, Lausanne

E. Zrenner, Tübingen
Printed in Switzerland on acid-free and non-aging paper (ISO 9706) by Reinhardt Druck, Basel
Appears 6-weekly: 2 volumes per yea (8 issues) 


\section{Ophthalmologica}

\section{Submission}

Original papers, reviews and carefully selected case reports written in English are considered for publication. Manuscripts should be submitted online

\section{www.karger.com/oph}

Should you experience any problems with your submission, please contact the Editorial Office at:

\section{oph@karger.com}

\section{Prof. J. Cunha-Vaz}

S. Karger AG

Editorial Office 'Ophthalmologica'

PO Box

$\mathrm{CH}-4009$ Basel (Switzerland)

Fax +4161306 1434

\section{Conditions}

All manuscripts are subject to editorial review. Manuscripts are received with the explicit understanding that they are not under simultaneous consideration by any other publication. A cover letter with the name, address, and telephone and telefax numbers of the corresponding author must accompany each manuscript. This letter must include a statement that affirms that all authors concur with the submission. Submission of an article for publication implies transfer of the copyright from the author to the publisher upon acceptance. Accepted papers become the permanent property of 'Ophthalmologica' and may not be reproduced by any means, in whole or in part, without the written consent of the publisher. It is the author's responsibility to obtain permission to reproduce illustrations, tables, etc. from other publications.

\section{Conflicts of Interest}

Authors are required to disclose any sponsorship or funding arrangements relating to their research and all authors should disclose any possible conflicts of interest. Conflict of interest statements will be published at the end of the article.

\section{Types of Papers}

Editorial

EURETINA - Review

EURETINA - Original Paper

Original Paper

Review

New Technologies in Ophthalmology

Letter to the Editor

Reviews are either invited, or may be submitted for consideration. Invited reviews, if accepted, are not subject to page charges. The recommended length is 6 printed pages (approx. 15 double-spaced manuscript pages).

Mini Reviews should contain an easy-to-read literature overview on a specific topic. Papers are either invited or may be submitted for consideration. Only concise articles of no more than 2 printed pages (approx. 6 doublespaced manuscript pages), including an abstract of max. 200 words and references, will be accepted. Please submit your mini review online.

\section{Letter to the Editor}

Letters are only accepted if they directly concern articles previously published in this journal and clinical subjects related to the matters discussed. The editor reserves the right to submit copies of such letters to the authors of the articles concerned prior to publication in order to permit them to respond in the same issue of the journal. Letters should have a maximum of one printed page (350-420 words, up to 8 references).

\section{Arrangement}

Title page: The first page of each paper should indicate the title, the authors' names, the institute where the work was conducted, and a short title for use as running head.

Full address: The exact postal address of the corresponding author complete with postal code must be given at the bottom of the title page. Please also supply phone and fax numbers, as well as e-mail address.

Key words: Please supply 3-10 key words in English that reflect the content of the paper.

Abstract: Each paper needs an abstract in English of not more than $\mathbf{1 5 0}$ words. The abstract is of utmost importance. It should contain the following information: purpose of the study, procedures, results, conclusions and message of the paper.

\section{Footnotes: Avoid footnotes}

Tables and illustrations: Tables and illustrations (both numbered in Arabic numerals) should be sent in separate files. Tables require a heading and figures a legend, also in a separate file. Due to technical reasons, figures with a screen background should not be submitted. When possible, group several illustrations in one block for reproduction (max. size $180 \times 223 \mathrm{~mm}$ ). Black and white half-tone and color illustrations must have a final resolution of $300 \mathrm{dpi}$ after scaling, line drawings one of $800-1,200 \mathrm{dpi}$.

\section{Color illustrations}

Online edition: Color illustrations are reproduced free of charge. In the print version, the illustrations are reproduced in black and white. Please avoid referring to the colors in the text and figure legends.

Print edition: Up to 6 color illustrations per page can be integrated within the text at CHF 800.- per page.

References: In the text identify references by Arabic numerals [in square brackets]. Material submitted for publication but not yet accepted should be noted as 'unpublished data' and not be included in the reference list. The list of references should include only those publications which are cited in the text. Do not alphabetize; number references in the order in which they are first mentioned in the text. The surnames of the authors followed by initials should be given. There should be no punctuation other than a comma to separate the authors. Preferably, please cite all authors. Abbreviate journal names according to the Index Medicus system. Also see International Committee of Medical Journal Editors: Uniform requirements for manuscripts submitted to biomedical journals (www.icmje.org).

Examples

(a) Papers published in periodicals: Chatel J-M, Bernard $\mathrm{H}$, Orson $\mathrm{FM}$ : Isolation and characterization of two complete Ara h 2 isoforms cDNA. Int Arch Allergy Immunol 2003;131:14-18.

(b) Papers published only with DOI numbers:

Theoharides TC, Boucher W, Spear K: Serum interleukin-6 reflects disease severity and osteoporosis in mastocytosis patients. Int Arch Allergy Immunol DOI: 10.1159/000063858.

(c) Monographs: Matthews DE, Farewell VT: Using and Understanding Medical Statistics, ed 3, revised. Basel, Karger 1996.(d) Edited books: DuBois RN: Cyclooxygenase-2 and colorectal cancer; in Dannenberg AJ, Dubois RN (eds): COX-2. Prog Exp Tum Res. Basel, Karger, 2003, vol 37, pp $124-137$.

Reference Management Software: Use of EndNote is recommended for easy management and formatting of citations and reference lists.

\section{Digital Object Identifier (DOI)}

S. Karger Publishers supports DOIs as unique identifier for articles. A DOI number will be printed on the title page of each article. DOIs can be useful in the future for identifying and citing articles published online without volume or issue information. More information can be found at www.doi.org.

\section{Supplementary Material}

Supplementary material is restricted to additional data that are not necessary for the scientific integrity and conclusions of the paper. Please note that all supplementary files will undergo editorial review and should be submitted together with the original manuscript. The Editors reserve the right to limit the scope and length of the supplementary material. Supplementary material must meet production quality standards for Web publication without the need for any modification or editing. In general, supplementary files should not exceed $10 \mathrm{MB}$ in size. All figures and tables should have titles and legends and all files should be supplied separately and named clearly. Acceptable files and formats are: Word or PDF files, Excel spreadsheets (only if the data cannot be converted properly to a PDF file), and video files (.mov, .avi, .mpeg).

\section{Author's Choice ${ }^{\mathrm{T}}$}

Karger's Author's Choice ${ }^{\mathrm{TM}}$ service broadens the reach of your article and gives all users worldwide free and full access for reading, downloading and printing at www. Karger.com. The option is available for a one-time fee of CHF 3000.-, which is a permissible cost in grant allocation. More information can be found at www.karger.com/ authors_choice.

\section{NIH-Funded Research}

The U.S. National Institutes of Health (NIH) mandates under the NIH Public Access Policy that final, peer-reviewed manuscripts appear in its digital database within 12 months of the official publication date. As a service to authors, Karger submits the final version of your article on your behalf to PubMed Central. For those selecting our premium Author's Choice ${ }^{\mathrm{TM}}$ service, we will send your article immediately upon publishing, accelerating the accessibility of your work without the usual embargo. More details on NIH's Public Access Policy is available at http://publicaccess.nih.gov/policy.htm

\section{Self-Archiving}

Karger permits authors to archive their pre-prints (i.e. prerefereeing) or post-prints (i.e. final draft post-refereeing) on their personal or institution's servers, provided the following conditions are met: Articles may not be used for commercial purposes, must be linked to the publisher's version, and must acknowledge the publisher's copyright. Authors selecting Karger's Author's Choice ${ }^{\mathrm{TM}}$ feature, however, are also permitted to archive the final, published version of their article, which includes copyediting and design improvements as well as citation links.

\section{Page Charges}

There are no page charges for papers of 3 or fewer printed pages (including tables, illustrations and references). Each additional complete or partial page is charged to the author at CHF 325.-. The allotted size of a paper is equal to approx. 8 manuscript pages (including tables, illustrations and references).

\section{Proofs}

Unless indicated otherwise, proofs are sent to the corresponding author and should be returned with the least possible delay. Alterations other than the correction of printer's errors are charged to the author.

\section{Reprints}

Order forms and a price list are sent with the proofs. Orders submitted after the issue is printed are subject to considerably higher prices.

\section{KARGER}

E-Mail karger@karger.com www.karger.com
(C) 2013 S. Karger AG, Basel 


\section{Ophthalmologica}

ISSN Print Edition: 0030-3755

ISSN Online Edition: 1423-0267

Journal Homepage: www.karger.com/oph

Publication Data: 'Ophthalmologica' is published 8 times a year. Volumes 229 and 230, each with 4 issues, appear in 2013.

Copyright: (c) 2013 S. Karger AG, Basel (Switzerland). All rights reserved. No part of this publication may be translated into other languages, reproduced or utilized in any form or by any means, electronic or mechanical, including photocopying, recording, microcopying, or by any information storage and retrieval system, without permission in writing from the publisher or, in the case of photocopying, direct payment of a specified fee to the Copyright Clearance Center.

Disclaimer: The statements, opinions and data contained in this publication are solely those of the individual authors and contributors and not of the publisher and the editor(s). The appearance of advertisements in the journal is not a warranty, endorsement, or approval of the products or services advertised or of their effectiveness, quality or safety. The publisher and the editor(s) disclaim responsibility for any injury to persons or property resulting from any ideas, methods, instructions or products referred to in the content or advertisements.
Subscription Rates: Subscriptions run for a full calendar year. Prices are given per year. Personal subscription:

Print or Online

CHF 1018.-

EUR 820.-

USD 1008.00

Print+Online combined CHF 1114.-

EUR 898.-

postage and handling (added to print and print+online)

CHF 57.60 Europe, CHF 83.20 Overseas

EUR 44.80

USD 76.80

Institutional subscription:

Print or Online

Print+Online combined

CHF 2034.

EUR 1640.-

CHF 2238.-

postage and handling (added to print and print+online)

CHF 72.- Europe, CHF 104.- Overseas

EUR 56.-

USD 96.00

Airmail surcharge: CHF 70.- / USD 66.00

Discount subscription prices:

- Association for Research and Vision in

Ophthalmology (ARVO)

- EVER

- EURETINA

- and other related societies
Back Volumes and Single Issues: Information on availability and prices of single print issues and print or electronic back volumes can be obtained from Customer Service atservice@karger.com.

Bibliographic Indices: This journal is regularly listed in bibliographic services, including Current Contents ${ }^{\circledR}$ and PubMed/MEDLINE.

Photocopying: This journal has been registered with the Copyright Clearance Center (CCC), as indicated by the code appearing on the first page of each article. For readers in the US, this code signals consent for copying of articles for personal or internal use, or for the personal or internal use of specific clients, provided that the stated fee is paid per copy directly to

Copyright Clearance Center Inc.

222 Rosewood Drive

Danvers, MA 01923 (USA)

A copy of the first page of the article must accompany payment. Consent does not extend to copying for general distribution, for promotion, for creating new works, or for resale. In these cases, specific written permission must be obtained from the copyright owner,

S. Karger AG, P.O. Box

CH-4009 Basel (Switzerland).

\begin{tabular}{|c|c|c|}
\hline \multirow{3}{*}{$\begin{array}{l}\text { Subscription Orders: } \\
\text { Orders can be placed at agencies, } \\
\text { bookstores, directly with the Publisher }\end{array}$} & or further Karger offices & USA \\
\hline & or representatives: & $\begin{array}{l}\text { S. Karger Publishers, Inc. } \\
26 \text { West Avon Road }\end{array}$ \\
\hline & Germany & P.O. Box 529 \\
\hline S. Karger AG & S. Karger GmbH & Unionville, CT 06085 \\
\hline Medical and Scientific Publishers & Postfach & USA \\
\hline Allschwilerstrasse 10 & 79095 Freiburg & Toll free: +1 8008285479 \\
\hline CH-4009 Basel & Deutschland & $\mathrm{t}: \quad+18606757834$ \\
\hline Switzerland & $\begin{array}{l}\text { (Hausadresse: Wilhelmstrasse 20A, } \\
79098 \text { Freiburg) }\end{array}$ & $\begin{array}{l}\mathrm{f}:+18606757302 \\
\text { e: karger@snet.net }\end{array}$ \\
\hline t: +41613061111 & $\mathrm{t}: \quad+49761452070$ & \\
\hline f: +41613061234 & $\mathrm{f}: \quad+497614520714$ & France \\
\hline e: karger@karger.com & e: information@karger.de & Librairie Médi-Sciences Sarl \\
\hline w: www.karger.com & w: www.karger.de & $\begin{array}{l}\text { 36, bd de Latour-Maubourg } \\
75007 \text { Paris }\end{array}$ \\
\hline (for courier services only: & Japan & France \\
\hline Allschwilerstrasse 10 & Karger Japan, Inc. & $\mathrm{t}: \quad+33(0) 145514258$ \\
\hline CH-4055 Basel) & Shiba Daimon Asahi Bldg. 2F & $\mathrm{f}: \quad+33(0) 145560780$ \\
\hline & 1-2-23 Shiba Daimon & e: librairie@medi-sciences.fr \\
\hline & Minato-ku & w: www.medi-sciences.fr \\
\hline & Tokyo 105-0012 & \\
\hline & Japan & \\
\hline & t: +81364356242 & \\
\hline & f: +81364356244 & \\
\hline & $\begin{array}{l}\text { e: publisher@karger.jp } \\
\text { w: www.karger.jp }\end{array}$ & \\
\hline
\end{tabular}

Change of Address:

Both old and new address should be sent

to the subscription source.

\section{KARGER}

E-Mail karger@karger.com www.karger.com
(C) 2013 S. Karger AG, Basel

The Journal Home Page is available at: www.karger.com/oph
South East Asia, China and Taiwan Karger Regional Office (Malaysia) CEO Suite Kuala Lumpur Quill 7, 27th Floor

Jalan Stesen Sentral 5

KL Sentral

Kuala Lumpur 50470

Malaysia

$\mathrm{t}:+60327766803$

f. +60327766999

e: service@karger.cn; r.chew@karger.cn

Karger China

10th Floor, Twin Towers (East)

B12 Jianguomenwai Avenue

Beijing 100022

China

t: +861051235033

$\mathrm{f}:$ +86 1051235122

e: service@karger.cn; r.chew@karger.cn

w: www.karger.cn

India, Bangladesh, Sri Lanka

Medscience India

Plot No. 17, Yusuf Sarai Market

B.L. Glass Building, 2nd Floor

Sri Aurobindo Marg

New Delhi 110016

India

t: +911146029633

f: +911146029634

c: +919891052128

e: medsci.india@gmail.com 


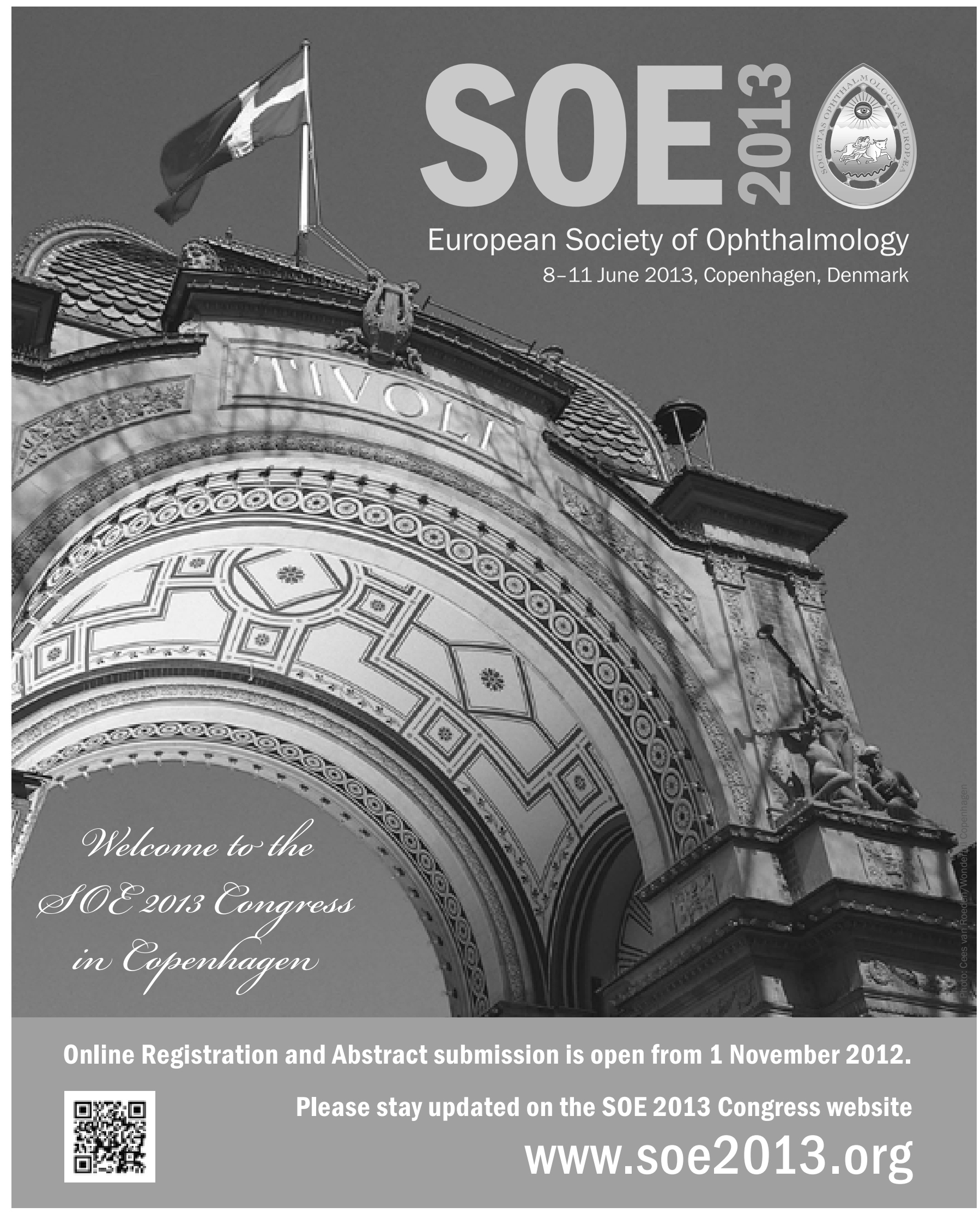




\title{
Transforming Vesalius
}

The medical revolution of the 16th century brought to life for the 21st century

\section{0 Vesalius}

\author{
ANDREAS VESALIUS
}

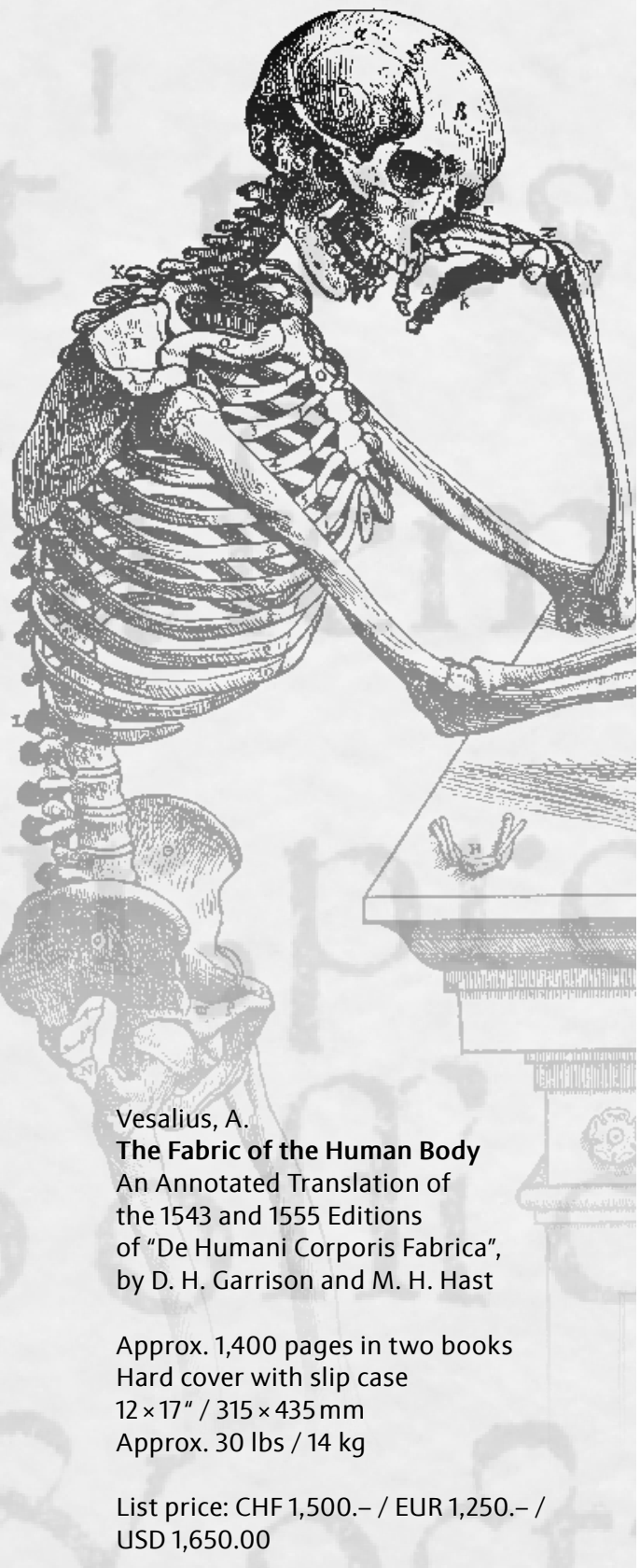

Pre-publication price: CHF 1,125.- /

EUR 935.- / USD 1,235.00

Valid until end of September 2013

Postage and handling included

VAT \& import taxes excluded

EUR price for Germany,

USD price for USA only

ISBN 978-3-318-02246-9

\section{The Fabric of the Human Body}

An Annotated Translation of the 1543 and 1555 Editions of "De Humani Corporis Fabrica" by

DANIEL H. GARRISON

MALCOLM H. HAST

- Modern layout enables the 21st-century reader to understand the complexity and pioneering nature of this milestone in medical history without the need of knowing Latin

- Different colors allow easy identification of notes relevant to both the 1543 and the 1555 editions

- Added notes for a never published third edition

- Up-to-date design and high-resolution digital scans of the woodcuts

- Nomina Anatomica and Terminologia Anatomica for the first time included to provide Vesalius' descriptions with modern medical terminology

- Prefaces by the translators and introductions by medical historians Vivian Nutton and Nancy Siraisi

Special pre-publication offer until September 2013

www.vesalius-fabrica.com 


\section{Contents}

See the journal website for contents

KARGER Basel $\bullet$ Freiburg $\cdot$ Paris $\bullet$ London $\bullet$ New York $\cdot$ New Delhi $•$ Bangkok Beijing $\cdot$ Tokyo $\cdot$ Kuala Lumpur $\cdot$ Singapore $\bullet$ Sydney 
JOIN EMINENT SURGEONS AT THE
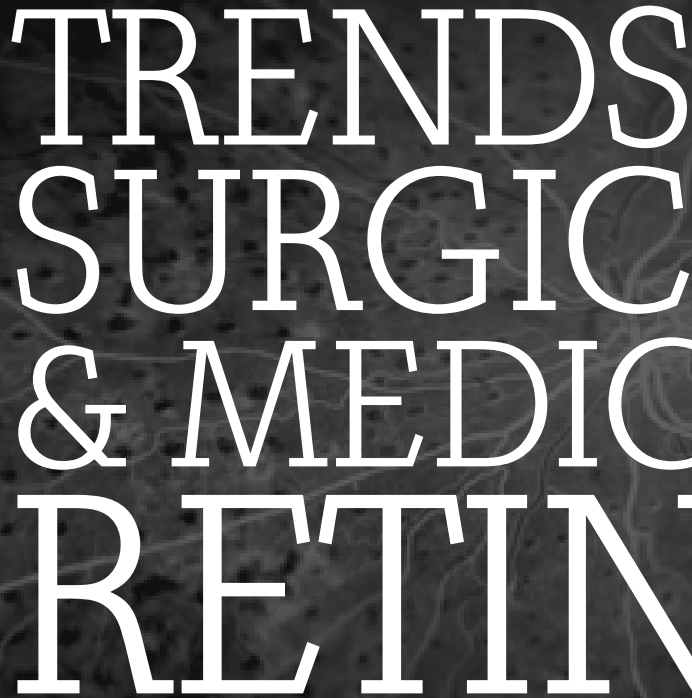

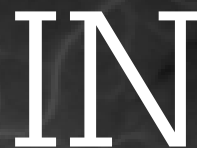

r
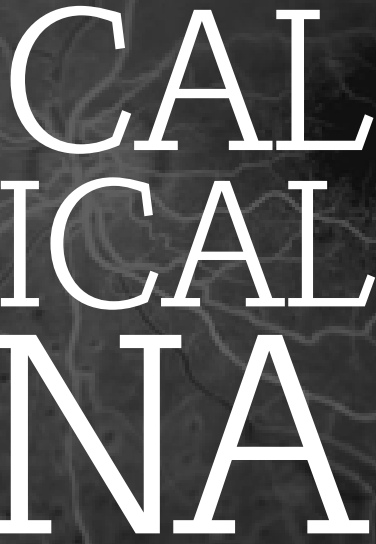

LIVE SURGERY \& ROUND TABLES SECOND MEETING

JUNE 7TH \& 8TH, 2013 IMO, BARCELONA

COORDINATOR:

BORJA CORCÓSTEGUI

Medical Director

Online registration is available

at www.imo.es/retinabarcelona

\section{FUNDACIÓN | IMO}

\section{IMO}

instituto de

microcirugía

ocular

\section{EVER EUROPEAN ASSOCIATION FOR VISION AND EYE RESEARCH}

EVER the European Association for Vision and Eye Research, is the leading ophthalmological research association in Europe which covers all areas of ophthalmology and the visual sciences. Membership is open to individuals of any nationality engaging in or with an interest in ophthalmic and vision research.

EVER 2013 will be held in France at the Nice Acropolis Convention Center from September 18-21, 2013.

\section{Join EVER}

- Largest annual european eye research meeting

- Special interest symposia

- Free paper sessions and posters

- Workshops and courses

- Lunchtime Commercial Interest Symposia

\section{Keynote Lectures}

- Keynote Lectures - Bal CHAUHAN, Canada - Alfredo SADUN, USA

Nicholas BAZAN, USA

- EVER Lecture - Leopold SCHMETTERER, Austria

- EVER - Acta Lecture - Tero KIVELÄ, Finland

- Ophthalmic Research Lecture - Neville Osborne, UK

- European Ophthalmic Heritage Lecture - Andrzej GRZYBOWSKI, Poland

Joint meetings with Acta Ophthalmologica, ARVO, EBO, EEBA, FAN club, FRO, ISCEV, KPro, OOG, SOIE

EVER Visit www.ever-f.eu for more information about the EVER foundation.

EVER $2014 \bullet$ Oct 1-4, Nice - joint meeting with EUPO EVER $2015 \bullet$ Oct 7-10, Nice 


\section{Targeting the mediators of inflammation ${ }^{1}$}
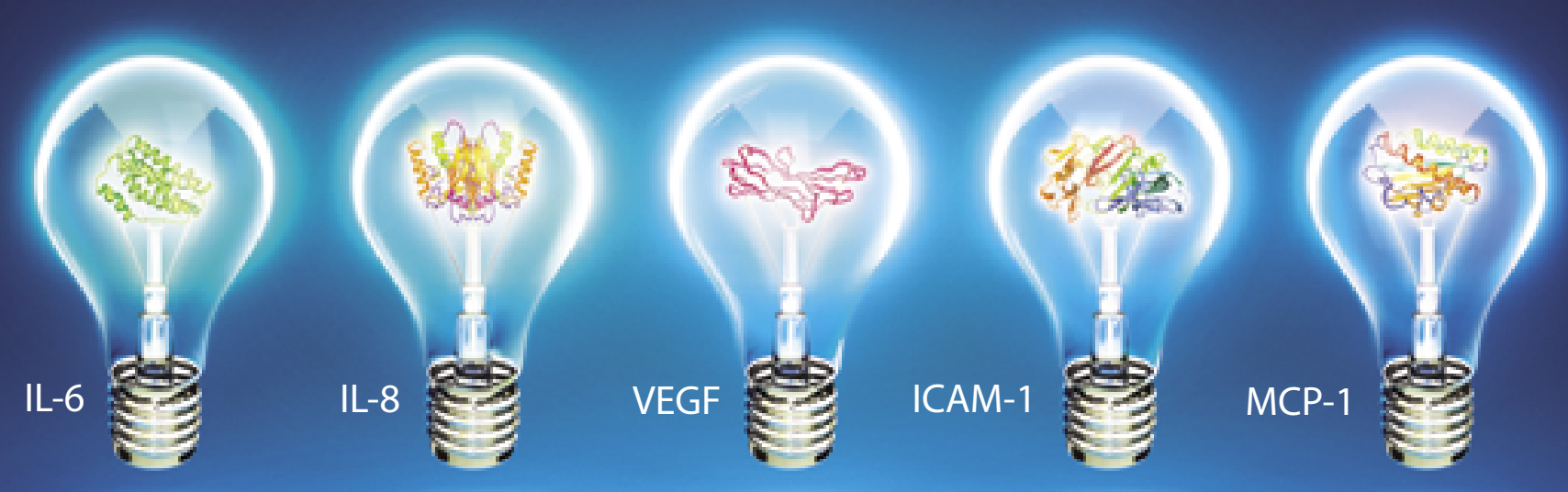

\section{Long-lasting vision improvement ${ }^{2-4}$}

OZURDEX ${ }^{\circ}$ (Dexamethasone 700 micrograms intravitreal implant in applicator) Abbreviated Prescribing Information

Presentation: Intravitreal implant in applicator. One implant contains 700 micrograms Presentation: Intravitreal implant in applicator. One implant contains 700 micrograns of dexamethasone. Disposable injection device, containing a rod-shaped implant which Indistions: Treatment of adult patients with macular aedema following either Branch Indications: Treatment of adult patients with macular oedema following either Branch Retinal Vein Occlusion (BRV) or Central Retinal Vein Occlusion (CRVO). Treatment of adul patients with infiamm a befits. Dosage and before prescribing. OZURDEX must be administered by a qualified ophthalmologis experienced in intravitreal injections. The recommended dose is one OZURDEX implant to is not recommended. Repeat doses should be considered when a patient experiences is not recommended. Repeat doses should be consided when a patient experiences epinion trat opinion may beneitit from retreatment without being exposed to significant risk. Patients a deterioration in vision, which is not slowed by OZURDEX, should not be retreated. There is only very limited inforion is only very limited information on repeat dosing intervals less than 6 months. There is uveitis or beyond 2 implants in Retinal Vein Occlusion. Patients should be monitored following the injetion to 2 ermit erly treatment if an infection or incresed in following the injection to permit early treatment if an infection or increased intraocula pressure occurs. No dose aujastment requad er elderly population $>65$ years). No specia population in populaton in acular oedema follow

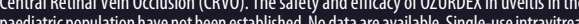
paediatric population have not been established. No data are available. Single-use intravitred he carried out under controlled asentic conditions which include the use of be carried out under controlled aseptic conditions Which include the use of sterile gloves a sterile drape, and a sterile eyelid speculum (or equivalent). A broad spectrum topica

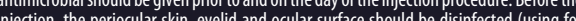
injection, the periocular skin, eyelid and ocular surface should be disinfected (using for example drops of povidone iodine $5 \%$ solution on the conjunctiva as it was done in the cinical triaps for the approval of OZU faministered. Remove the foll pouch from the carton and examine for damage. In a sterile lo immediately. Hold the applicator in one hand and pull the safety tab straight off the applicator. Do not twist or flex the tab. With the bevel of the needle up away from the sclera, advance the needle about $1 \mathrm{~mm}$ into the sclera then redirect toward the centre of the eye into the vitreous cavity until the silicone sleeve is against the conjunctiva. Slowly press the actuator button until an audible click is noted. Before withdrawing the applicator from the eye, make sure that the actuator button is fully pressed and has locked flush with the applicator surface. Remove the needle in the same direction as used to enter the vitreous. Immediately after injecting OZURDEX, use indirect ophthalmoscopy in the quadrant of injection to confirm successuul implantation. Visualisation is possible in the large majority of cases. In cases in which the implant cannot be visualised, take a sterile cotton bud and lightly depress over the injection site to bring the implant into view. Following the intravitreal injection patients should continue to be treated with a broad spectrum antimicrobial. Activers Active or suspected ocular or periocular infection including most viral diseases of the cornea and conjunctiva, including active epithelial herpes simplex keratitis (dendritic keratitis), vacen cannot be adequately controlled by medicinal products alone. Aphakic eyes with rupture of the posthe rupture of the posterior lens capsule. Warnings/Precautions: Any intravitreous injection

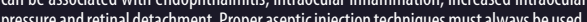
patsents shol be do Parins a dintran the oticnere hed im the injection and biomicoscop betreen the injection, and biomicroscopy between two and seven days following the injection. of the abore mentioned events with out All patients of the abore mentioned events those with a posterior lens, and/or those who have an iris defect (e.g. due to iridectomy) chath 0 . OZUPDEY Oh han those pate OZRDEX should be used with caution and only following a careful risk benefit assessment.

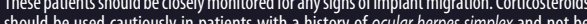
should be used cautiously in patients with a history of ocular herpes simplex and not be soth eyes cocure both eyes Concurstis recommended in patients with macular oedema secondary to $\mathrm{KV} O$ with significant retinal scher in ozun platelet medicinal products. Imteractions: No interaction studies have been performed. no adequate data from the use of intravitreally administered dexamethasone in pregnant vomen. OZURDEX is not recommended during pregnancy unless the potential benefit justifies the potential risk to the foetus. Lactation: Dexamethasone is excreted in breast milk. No effects on the child are anticipated due to the route of administration and the resulting systemic levels. However OZURDEX is not recommended during breast feeding unless clearly necessary. Driving/Use of Machines: Patients may experience temporarily reduced vision after receiving OZURDEX by intravitreal injection. They should not drive or use machines until this has resolved. Adverse Effects: RVO In clinical trials the most frequently reported adverse events were increased intraocular pressure (24.0\%) and conjunctival haemorrhage $(14.7 \%)$. Increased intraocular pressure (IOP) with OZURDEX peaked at day 60 and returned to baseline levels by day 180 . Elevations of IOP either did not require treatment or were managed with the temporary use of topical IOP-lowering medicinal products. The following adverse events were reported: Eve disorders Very common $(\geq 1 / 10)$ Intraocular pressure increased, conjunctival haemorrhage ${ }^{*}$ Common $(\geq 1 / 100$ to $<1 / 10)$ Ocular hypertension, vitreous detachment, cataract, subcapsular cataract, vitreous haemorrhage*, visual disturbance, vitreous opacities* (including vitreous floaters), eye pain ${ }^{*}$, photopsia*, conjunctival oedema* , anterior chamber cell ${ }^{*}$, conjunctival hyperaemia Uncommon $(\geq 1 / 1,000$ to $<1 / 100)$ Retinal tear*, anterior chamber flare* Nervous system disorders Common: Headache. Uveitis In clinical trials the most frequently reported adverse events in the study eye were conjunctival haemorrhage $(30.3 \%)$, increased intraocular pressure $(25.0 \%)$ and cataract $(11.8 \%)$. The following adverse events were reported: Nervous system disorders Common: Migraine Eve disorders Very common: Increased intraocul (1)

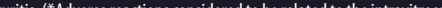
injection procedure rather than the dexamethasone implant). Please refer to Summary of Product Characteristics for full information on side effects. Marketing Authorisation number: EU/1/10/638/001 Marketing Authorisation Holder: Allergan Pharmaceuticals Ireland, Castlebar Road, Westport, Co. Mayo, Ireland. Legal Category: POM. Date of Preparation: October 2012

Adverse events should be reported to your local Allergan office and to your Regulatory Authority. 


\section{Vision in focus}

\section{Ophthalmic Research}

Journal for Translational and Clinical Research

Editors
B. Corcóstegui, Barcelona
D.E. Pelayes, Buenos Aires
U. Pleyer, Berlin

Impact Factor: 1.561

\section{Ophthalmic Research}

Official Journal of the

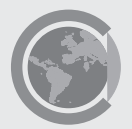

EuroLam

RETINA

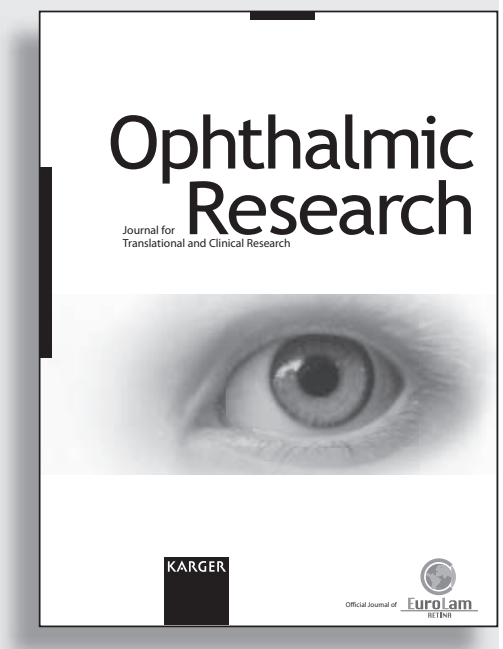

More information at

\section{www.karger.com/ore}

- Pay-per-View and Subscriber Access

to Full Text

- Full Table of Contents

- Full Editorial Board

- Free Abstracts and Selected Articles

- Online Sample Issue

- Submission/Guidelines for Authors

- Subscription Details

- Free Alert Service

- Online Library Recommendation

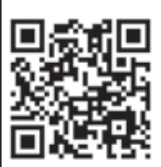

0phthalmic Research

2013: Volume 49, 50

4 issues per volume

Language: English

ISSN 0030-3747 (print)

ISSN 1423-0259 (online)

Listed in bibliographic services, including

Current Contents $\% /$ Life Sciences,

Pubmed/MEDLINE, Biological Abstracts

\section{Selected contributions}

- Prevention of Corneal Neovascularization: Comparison of Different Doses of Subconjunctival Bevacizumab with Its Steroid-Induced latrogenic Glaucoma: Razeghinejad, M.R. (Shiraz/Philadelphia, Pa.); Katz, L.J. (Philadelphia, Pa.)

- Steroid-Induced latrogenic Glaucoma: Razeghinejad, M.R. (Shiraz/Philadelphia, Pa.); Katz, L.J. (Philadelphia, Pa.)

- The Eye as a Common Site for the Early Clinical Manifestation of Sarcoidosis: Heiligenhaus, A. (Münster); Wefelmeyer, D.; Wefelmeyer, E. (Bochum); Rösel, M. (Münster); Schrenk, M. (Rheinfelden/Höchenschwand)

- Comparison between One Injection and Three Monthly Injections of Intravitreal Bevacizumab for Myopic Choroidal Neovascularization: Niwa, Y.; Sawada, 0.;

Miyake, T.; Kakinoki, M.; Sawada, T.; Kawamura, H.; Ohji, M. (Otsu)

- Effect of Intravitreal Anti-Vascular Endothelial Growth Factor Treatment on the Retinal Gene Expression in Acute Experimental Central Retinal Vein Occlusion: Drechsler, F.; Köferl, P.; Hollborn, M.; Wiedemann, P.; Bringmann, A. (Leipzig);

Kohen, L. (Leipzig/Aue); Rehak, M. (Leipzig)

- The Effects of Corneal Endothelium on Graft Survival in a Murine Model of

Lamellar Keratoplasty: Huang, T. (Guangzhou); Lee, E.J.; Planck, S.R.; Rosenbaum, J.T. (Portland, Oreg.)

- Role of Inferior Orbital Wall Morphologic Properties in Isolated Orbital Blow-Out Fracture: Park, J.-S.; Lew, H. (Seongnam); Lee, S.-Y. (Seoul)

- Pharmacological Enhancement of ex vivo Gene Therapy Neuroprotection in a Rodent Model of Retinal Degeneration: Gregory-Evans, K. (Vancouver, B.C./London); Po, K. (Vancouver, B.C.); Chang, F. (London); Gregory-Evans, C.Y. (Vancouver, B.C./London)
Ophthalmic Research features original papers, reviews and short communications reporting on translational and clinical studies. Authors from throughout the world cover topics on glaucoma, cataract and refractive surgery, retina, uveitis, and other fields in connection with physical, physiologic, pharmacological, biochemical and molecular biological aspects of ophthalmology. This journal provides a record of international clinical research for both researchers and clinicians in ophthalmology.

The journal further offers, at a reasonable price, the possibility of publishing dedicated supplements and abstracts of conferences and symposia. Please consult the managing editor for this. 


\section{Ophthalmologica}

EURETINA - Review

125 Retinal Vascular Caliber Measurements: Clinical Significance, Current Knowledge and Future Perspectives

Ikram, M.K. (Singapore/Rotterdam); Ong, Y.T.; Cheung, C.Y.; Wong, T.Y. (Singapore)

EURETINA - Original Papers

137 Early Effects of Pars Plana Vitrectomy Combined with Intravitreal Gas Tamponade on Corneal Biomechanics

Teke, M.Y.; Elgin, U.; Sen, E.; Ozdal, P.; Ozturk, F. (Ankara)

142 Systemic Factors Influence the Prognosis of Diabetic Macular Edema after Pars Plana Vitrectomy with Internal Limiting Membrane Peeling

Yamada, Y.; Suzuma, K.; Kumagami, T.; Fujikawa, A.; Kitaoka, T. (Nagasaki)

147 Characterization of Neovascular Age-Related Macular Degeneration Patients with Outer Retinal Tubulations

Faria-Correia, F.; Barros-Pereira, R.; Queirós-Mendanha, L.; Fonseca, S.; Mendonça, L.; Falcão, M.S.; Brandão, E.; Falcão-Reis, F.; Carneiro, A.M. (Porto)

152 Intravitreal Ranibizumab for Acute Central Serous Chorioretinopathy Kim, M.; Lee, S.-C.; Lee, S.-J. (Chuncheon)

Original Papers

158 Treatment of Exudative Age-Related Macular Degeneration with Intravitreal Ranibizumab in Clinical Practice: A 3-Year Follow-Up

Marques, I.P.; Fonseca, P.; Luz Cachulo, M.; Pires, I.; Figueira, J.; Faria de Abreu, J.R.; Silva, R. (Coimbra)

168 Long-Term Intraocular Pressure Changes in Patients with Neovascular Age-Related Macular Degeneration Treated with Ranibizumab

Menke, M.N. (Bern); Salam, A. (Pahang); Framme, C.; Wolf, S. (Bern)

173 Clinical Pattern of Toxoplasmic Retinochoroiditis in a Spanish Referral Center Rey, A.; Llorenç, V.; Pelegrín, L.; Mesquida, M.; Molins, B.; Rios, J. (Barcelona); Arévalo, J.F. (Baltimore, Md./Riyadh); Adán, A. (Barcelona)

179 Book Review 